\title{
Solid State Cathode Materials for Secondary Magnesium-Ion Batteries that are \\ Compatible with Magnesium Metal Anodes in Water-free Electrolyte
}

\author{
Adam J. Crowe and Bart M. Bartlett* \\ Department of Chemistry, University of Michigan \\ 930 N. University Avenue \\ Ann Arbor, MI 48109-1055 \\ bartmb@umich.edu
}

Keywords magnesium-ion battery cathodes

\begin{abstract}
With high elemental abundance, large volumetric capacity, and dendrite-free metal deposition, magnesium metal anodes offer promise in beyond-lithium-ion batteries. However, the increased charge density associated with the divalent magnesium-ion $\left(\mathrm{Mg}^{2+}\right)$, relative to lithium-ion $\left(\mathrm{Li}^{+}\right)$ hinders the ion-insertion and extraction processes within many materials and structures known for lithium-ion cathodes. As a result, many recent investigations incorporate known amounts of water within the electrolyte to provide temporary solvation of the $\mathrm{Mg}^{2+}$, improving diffusion kinetics. Unfortunately with the addition of water, compatibility with magnesium metal anodes disappears due to forming an ion-insulating passivating layer. In this short review, recent advances in solid state cathode materials for rechargeable magnesium-ion batteries are highlighted, with a focus on cathode materials that do not require water contaminated electrolyte solutions for ion insertion and extraction processes.
\end{abstract}

\section{Introduction}

Lithium-ion batteries now power devices on multiple size and energy scales—from portable electronics to hybrid electric vehicles.[1] With technology revolving around lithium, which is relatively scarce (18 ppm)[2], next-generation batteries are becoming increasingly sought after. Magnesium-based batteries have been proposed as a viable candidate owing to the 
high natural abundance of magnesium (2.3\% of Earth's crust)[2] and the fact that magnesium possesses a theoretical volumetric energy density twice that of lithium due to its divalent cation.[3] Magnesium metal anodes offer improved operational safety due to non-dendritic deposition and decreased air sensitivity compared to lithium metal.[4-6] However, magnesiumbased technology remains hindered by unstable electrolytes and by cathode materials with too low an electrode potential.[7]

Despite the widespread commercial success of lithium-ion technologies, adapting its components for the rapid propulsion of magnesium-ion batteries has not been successful. There is little correlation between the chemistry of the two metal anodes besides the formation of passivation layers in the presence of many common inorganic salts and solvents.[8] In the case of lithium, electrolyte decomposition results in the growth of a solid electrolyte interface (SEI) layer. Subsequent stabilization of charge-discharge cycles is achieved since ions diffuse through while electron transfer is inhibited.[9] An analogous passivation film develops for $\mathrm{Mg}^{2+}$, with the notable difference that cation diffusion is also restricted,[10] prohibiting magnesium anodeelectrolyte compositions from including simple magnesium salts $\left(\mathrm{Mg}\left(\mathrm{ClO}_{4}\right)_{2}, \mathrm{Mg}(\mathrm{TFSI})_{2}\right.$, and $\left.\operatorname{Mg}\left(\mathrm{BF}_{4}\right)_{2}\right)$ or aprotic solvents besides ethers.[5] While many metal oxide cathode materials demonstrate excellent electrochemical cycling characteristics within lithium-ion batteries, inferior electrochemical properties are observed in analogous magnesium-based batteries.

Desired characteristics for good electrodes include small particle size and/or rapid ion diffusion for high power cycling (rate capability), large operating potential, and structural rigidity for long term cycling with minimal capacity fade. A selection of parameters for the electrode materials featured in this report is presented within Table 1, and further discussed in the following sections. A key difference in moving diagonally from lithium to magnesium is 
Table 1. Parameters for Cathode Material Performance.

\begin{tabular}{cccccc}
\hline $\begin{array}{c}\text { Cathode } \\
\text { Material }\end{array}$ & $\begin{array}{c}\text { Potential Window / } \\
\text { V vs. } \mathrm{Mg}^{2+/ 0}\end{array}$ & $\begin{array}{c}\text { Gravimetric Capacity/ } \\
\mathrm{mAh} \mathrm{g}^{-1}\end{array}$ & $\begin{array}{c}\text { Cycle Rate / } \\
\mathrm{mA} \mathrm{g}^{-1}\end{array}$ & $\begin{array}{c}\text { Capacity } \\
\text { Retention / } \\
\text { Cycle Number }\end{array}$ & Ref. \\
\hline${\mathrm{CP}-\mathrm{Mo}_{6} \mathrm{~S}_{8}}$ & $0.2-2.0$ & 100 & $15^{[\mathrm{a}]}$ & $95 \% / 100$ & {$[11]$} \\
$\mathrm{MoS}_{2}$ & $0.5-3.0$ & 170 & 20 & $95 \% / 50$ & {$[12]$} \\
$\mathrm{WSe}_{2}$ & $0.3-3.0$ & 203 & 50 & $100 \% / 160$ & {$[13]$} \\
$\mathrm{MoO}_{3}$ & $1.4-2.7$ & 150 & $0.01-0.02$ & $67 \% / 4$ & {$[14]$} \\
$\alpha-\mathrm{MnO}_{2}$ & $0.8-3.0$ & 240 & $1.5^{[\mathrm{b}]}$ & $50 \% / 3$ & {$[15]$} \\
\hline
\end{tabular}

Converting $C$-rate to current density in $\mathrm{mA} \mathrm{g}^{-1}$ using the following stoichiometric formulas [a]

$\mathrm{Mg}_{2} \mathrm{Mo}_{6} \mathrm{~S}_{8}$ (reported as C/8) [16] and [b] $\mathrm{Mg}_{4} \mathrm{Mo}_{6} \mathrm{~S}_{12}$ (reported at 0.015 C) [12]

that with the strong electrostatic coordination of divalent magnesium within the oxide host, solid state diffusion becomes the rate-determining step[17,18], and calculated diffusivities are as low as $10^{-15} \mathrm{~cm}^{2} / \mathrm{s}$.[19] Battery cycling within oxides are drastically improved upon with the addition of $\mathrm{H}_{2} \mathrm{O}$, attributed to the strong donor contribution and temporary solvation of the hard magnesium cation, leading to enhanced diffusion kinetics.[14,20,21] Although as mentioned previously, use of water-contaminated electrolyte precludes compatibility with magnesium metal anodes due to the development of a passivating oxide film.

Despite the added complexity of magnesium anode-electrolyte compatibility, cathode design and synthesis continues to be an interest amongst researchers. The outcome of these pursuits has generated many advancements that are compiled within several recent review articles.[3,22-24] Therefore, the aim of this review is highlight the specific challenge of cycling solid-state cathodes against a magnesium metal anode without using a water-contaminated electrolyte. This strategy, in our view, is the only way magnesium-ion batteries will emerge as a competitive technology. This short review serves as a guide for design of cathodes that harness the maximum capacity of magnesium metal anodes. In addition, we present existing materials that have already demonstrated such compatibility with magnesium metal anodes, which will aid the search for new electrolytes. 


\section{Chalcogenide Based-Cathode Materials}

2.1. $\mathrm{Mo}_{6} \mathrm{~S}_{8}$

First recognized in 2000 by Aurbach and coworkers, the Chevrel-phase $\mathrm{Mo}_{6} \mathrm{~S}_{8}$ (CP$\mathrm{Mo}_{6} \mathrm{~S}_{8}$ ) serves as an excellent host for reversible $\mathrm{Mg}^{2+}$ insertion and extraction.[7] Through a molten salt synthesis of $\mathrm{Cu}_{2} \mathrm{Mo}_{6} \mathrm{~S}_{8}$, followed by copper removal, the $\mathrm{CP}-\mathrm{Mo}_{6} \mathrm{~S}_{8}$ synthesis is easily scalable for manufacturing purposes.[25] A cubic arrangement of sulfur atoms, where octahedral clusters of molybdenum present two possible cavities for insertion-labeled Cavity 1 and Cavity 2 by the authors in Figure 1. Cavity 3 cannot be occupied due to strong electrostatic repulsion of molybdenum and magnesium. Upon insertion of $\mathrm{Mg}^{2+}$, with the concomitant reduction of $\mathrm{CP}-\mathrm{Mo}_{6} \mathrm{~S}_{8}$ to form rhombohedral $\mathrm{MgMo}_{6} \mathrm{~S}_{8}$, a high activation barrier exists for $\mathrm{Mg}^{2+}$ migration between alternative cavities. With additional ion insertion both ionic transport and insertion rates are enhanced when $x$ is greater than 1 in $\mathrm{Mg}_{x} \mathrm{Mo}_{6} \mathrm{~S}_{8}$, due to cationic repulsion.[16] In the initial report, the salt identified as $\mathrm{Mg}\left(\mathrm{AlCl}_{2} \mathrm{BuEt}\right)_{2}$ in $\mathrm{THF}(0.25 \mathrm{M})$ facilitated the insertion/extraction processes with more than 2,000 cycles demonstrated, at current densities between $0.1-1$ $\mathrm{mA} \mathrm{cm}^{-2}$ with $<15 \%$ capacity fade observed.[7] Despite a low voltage window $\left(0.2-2.0 \mathrm{~V}\right.$ vs. $\left.\mathrm{Mg}^{2+/ 0}\right)$ and irreversible capacity loss, $\mathrm{CP}-\mathrm{Mo}_{6} \mathrm{~S}_{8}$ has been and continues to be featured in many electrolyte reports. It serves as the standard cathode material for

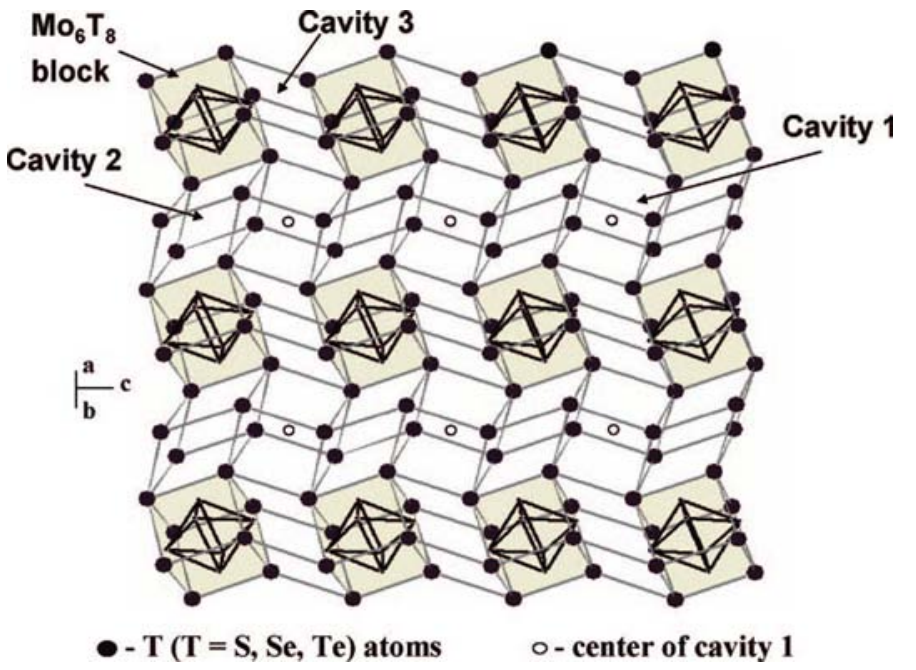

Figure 1 Magnesium intercalation cavities within CP$\mathrm{Mo}_{6} \mathrm{~T}_{8}$. Reprinted (adapted) with permission from $\mathrm{E}$. Levi, G. Gershinsky, D. Aurbach, O. Isnard, G. Ceder, Chem. Mater., 21 (2009) 1390-1399. Copyright (2009) American Chemical Society. 

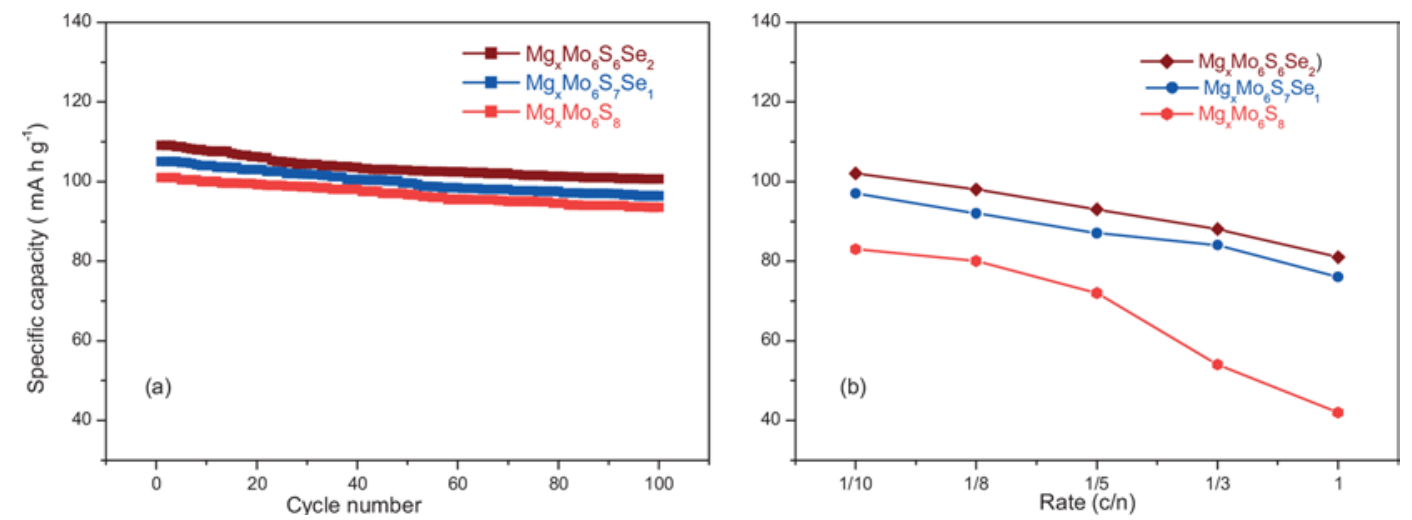

Figure 2 Capacity vs. cycle number (a) and capacity vs. rate curves (b) of various $\mathrm{Mg}_{x} \mathrm{Mo}_{6} \mathrm{~S}_{8-y} \mathrm{Se}_{y}(y=0,1,2)$. Reprinted (adapted) with permission from D. Aurbach, G.S. Suresh, E. Levi, A. Mitelman, O. Mizrahi, O. Chusid, M. Brunelli, Adv. Mater. 19 (2007) 4260-4267. Copyright (2007) WILEY-VCH Verlag GmbH \& Co. KGaA, Weinheim.

demonstrating reversible $\mathrm{Mg}^{2+}$ insertion and extraction from new electrolyte formulations.

With partial substitution of sulfur with selenium in $\mathrm{Mo}_{6} \mathrm{~S}_{8-x} \mathrm{Se}_{x}(0<x<2)$, the increase in framework polarizability gives rise to improved battery electrochemistry, illustrated in Figure 2.[11] As the selenium content increases, the specific capacity and rate capability follow. Reduction in partial ion-trapping is also observed with sulfide substitution, arising from the distortion of the $\mathrm{Mg}^{2+}$ coordination sites with the larger chalcogenides. Selenide allows for enhanced ion hopping between $\mathrm{Mg}^{2+}$ sites.[18]'[26] The end member compositions $\mathrm{Mg}_{x} \mathrm{Mo}_{6} \mathrm{Se}_{8}$ $(0<x<2)$ show high $\mathrm{Mg}^{2+}$ mobility throughout the entire insertion process.[27] Additionally, electrodes composed of $\mathrm{Mg}_{x} \mathrm{Mo}_{6} \mathrm{~S}_{6} \mathrm{Se}_{2}$ demonstrated superior rate capabilities relative to $\mathrm{Mg}_{x} \mathrm{Mo}_{6} \mathrm{~S}_{8}$ at $1 \mathrm{C}$, where observed losses in gravimetric capacities were $10 \%$ and $50 \%$ for $\mathrm{Mg}_{x} \mathrm{Mo}_{6} \mathrm{~S}_{6} \mathrm{Se}_{2}$ and $\mathrm{Mg}_{x} \mathrm{Mo}_{6} \mathrm{~S}_{8}$ respectively.

\section{$2.2 \mathrm{MoS}_{2}$}

With two layers of sulfur atoms sandwiching molybdenum cations between, as illustrated in Figure 3, $\mathrm{MoS}_{2}$ represents a suitable framework for $\mathrm{Mg}^{2+}$ intercalation/deintercalation. Initial 

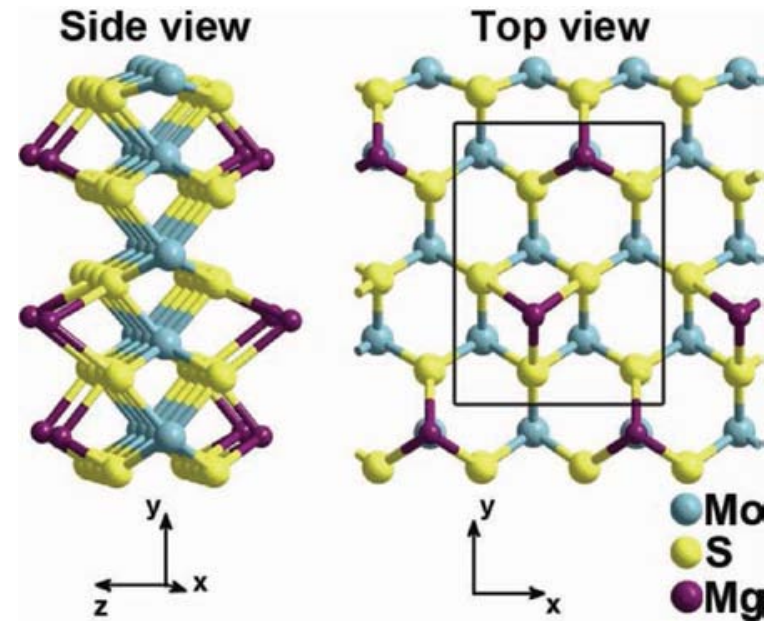

Figure 3 Theoretical model of $\mathrm{Mg}^{2+}$ intercalation within an $\mathrm{MoS}_{2}$ single-layered nano-ribbon. Reprinted (adapted) with permission from Y. Liang, R. Feng, S. Yang, H. Ma, J. Liang, J. Chen, Adv. Mater. 23 (2011) 640-643. Copyright (2011) WILEY$\mathrm{VCH}$ Verlag GmbH \& Co. KGaA, Weinheim.

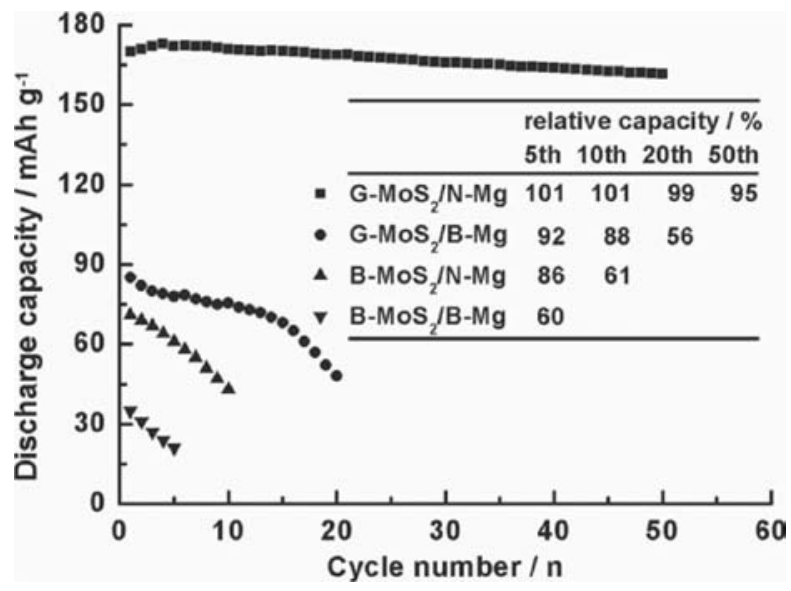

Figure 4. Cycling behavior of $\mathrm{G}-\mathrm{MoS}_{2}$ (graphene-like $\quad \mathrm{MoS}_{2}$ ), $\mathrm{N}-\mathrm{Mg} \quad$ (magnesium nanoparticle anode), B-MoS $\left(\right.$ bulk $\mathrm{MoS}_{2}$ ), and B-Mg (bulk magnesium). Reprinted (adapted) with permission from Y. Liang, R. Feng, S. Yang, H. Ma, J. Liang, J. Chen, Adv. Mater. 23 (2011) 640-643. Copyright (2011) WILEY-VCH Verlag GmbH \& Co. KGaA, Weinheim.

nanostructured materials (hollow-cage fullerene-like particles, fibrous floccus, and spherical nanovesicles), prepared through solution-based chemical reactions demonstrated low insertion and extraction capacities (2 - $25 \mathrm{mAh} / \mathrm{g})$ at $2.9 \mathrm{~mA} / \mathrm{g}$ charging and $1.2 \mathrm{~mA} / \mathrm{g}$ discharging rates while using an electrolyte solution composed of $0.25 \mathrm{M} \mathrm{MgBu}_{2}$ and $0.5 \mathrm{M} \mathrm{AlCl}_{3}$ electrolyte in THF solvent.[28] However, $\mathrm{MoS}_{2} / \mathrm{C}$ microspheres and an AZ31 (3 wt-\% Al, 1 wt-\% Zn, 96 wt-\% $\mathrm{Mg}$ ) alloy anode shows an initial discharge capacity of $213 \mathrm{mAh} / \mathrm{g}$ using $\mathrm{Mg}\left(\mathrm{AlCl}_{3} \mathrm{Bu}\right)_{2}$ salt dissolved in THF solvent (at $50 \mathrm{~mA} / \mathrm{g}$ ). While the exact electrolyte concentrations were not specified, typical electrolyte solutions containing magnesium organohaloaluminate salts are 0.25 $\mathrm{M}$ in THF solvent. Subsequent cycles show a significant capacity fade $(84.3 \mathrm{mAh} / \mathrm{g})$ loss after 50 cycles) due to the growth of passivating films on the Mg-anode. Nonetheless the superior performance, relative to bulk-MoS , is owed to the improved $\mathrm{Mg}^{2+}$ diffusivity through $\mathrm{MoS}_{2}$ 
microspheres and enhanced electronic conductivity from the carbon coating. [29] Comparing the values of Re (resistance from electrolyte, electrode, and passivation film between the two) and $R_{\mathrm{ct}}$ (charge-transfer resistance), a decrease from $33.6 \Omega$ and $1167 \Omega$ to $17.82 \Omega$ and $218 \Omega$ is observed between annealed $\mathrm{MoS}_{2}$ and the $\mathrm{MoS}_{2} / \mathrm{C}$ composite, respectively. With emphasis on morphology control and design, a graphene-like $\mathrm{MoS}_{2}$ cathode demonstrates an operating voltage of $1.8 \mathrm{~V}$ vs. $\mathrm{Mg}^{2+/ 0}$ and a discharge capacity of $170 \mathrm{mAh} / \mathrm{g}$ (at $20 \mathrm{~mA} / \mathrm{g}$ ) when paired with a Mg nanoparticle anode and an electrolyte solution composed of $0.25 \mathrm{M} \mathrm{MgBu}_{2}$ and $0.5 \mathrm{M}$ $\mathrm{AlCl}_{3}$ electrolyte in THF solvent. Most notably, Figure 4 illustrates that this combination shows minimal capacity fade, retaining 95\% capacity after 50 discharge-charge cycles.[12] Cells constructed with magnesium nanoparticle anodes $(\mathrm{N}-\mathrm{Mg})$ demonstrated improved performance due to the generation of thinner passivation films relative to bulk magnesium metal anodes (BMg), as they possess substantially larger surface area than B-Mg.[30] It is clear that graphenelike $\mathrm{MoS}_{2}\left(\mathrm{G}-\mathrm{MoS}_{2}\right)$ outperforms bulk-MoS $\left(\mathrm{B}-\mathrm{MoS}_{2}\right)$, likely due to the bifacial $\mathrm{Mg}$ intercalation into expanded $\mathrm{MoS}_{2}$ single layers.[31]

$2.3 \mathrm{WSe}_{2}$

The layered chalcogenide $\mathrm{WSe}_{2}$, which is isostructural to $\mathrm{MoS}_{2}$, has also been employed as a cathode material for rechargeable $\mathrm{Mg}^{2+}$ batteries. $\mathrm{WSe}_{2}$ nanowires with an average diameter of 100 nm, prepared via chemical vapor deposition, demonstrate a reversible specific capacity of

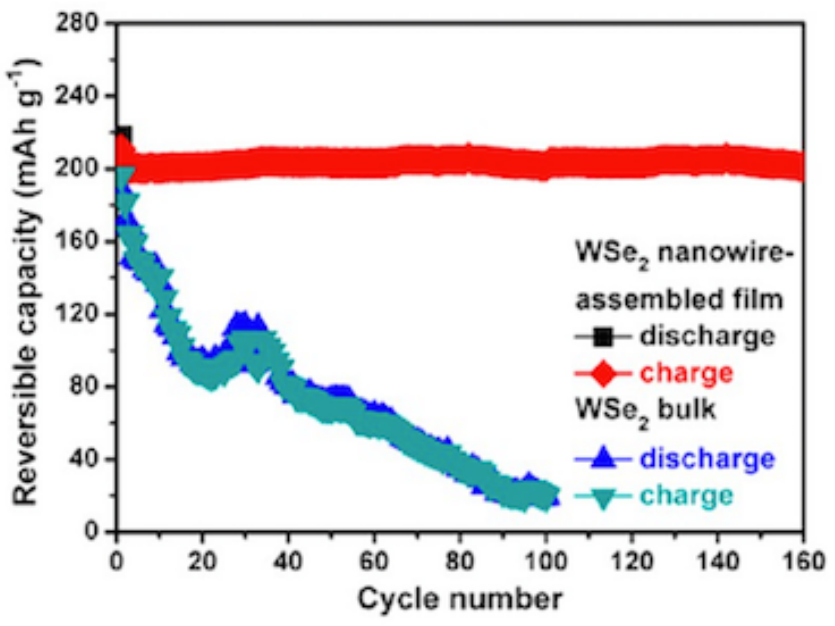

Figure 5. Comparison of cycling behavior between bulk $\mathrm{WSe}_{2}$ and $\mathrm{WSe}_{2}$ nanowire-based electrodes. Reprinted (adapted) with permission from B. Liu, T. Luo, G. Mu, X. Wang, D. Chen, G. Shen, ACS Nano 7 (2013) 8051-8058. Copyright (2013) American Chemical Society. 
$203 \mathrm{mAh} / \mathrm{g}$ (at $50 \mathrm{~mA} / \mathrm{g}$ ), when employing $\mathrm{Mg}\left(\mathrm{AlCl}_{2} \mathrm{BuEt}\right)_{2}$ electrolyte in THF ( $\left.0.25 \mathrm{M}\right)$ between $0.3-3 \mathrm{~V}$ vs. $\mathrm{Mg}^{2+/ 0}$ for over 160 cycles.[13] The rate capability was measured, and the nanowires show a capacity of $142 \mathrm{mAh} / \mathrm{g}$ at $800 \mathrm{~mA} / \mathrm{g}$. Further investigation showed that current densities as high as 1500 and $3000 \mathrm{~mA} / \mathrm{g}$ delivered capacities of 120 and $103 \mathrm{mAh} / \mathrm{g}$, respectively. In the same report, bulk $\mathrm{WSe}_{2}$ was examined, showing dramatically inferior cycling characteristics - only 10\% capacity retention after 100 cycles (Figure 5). One cause of battery failure is that the cells were operated at potentials greater than the anodic stability the electrolyte (2.4 V vs. $\mathrm{Mg}^{2+/ 0}$ ).[7] Our group has demonstrated reversible $\mathrm{Mg}^{2+}$ intercalationdeintercalation with bulk WSe 2 using a $0.5 \mathrm{M} \mathrm{Al}(\mathrm{OPh})_{3}-\mathrm{PhMgCl}$ in THF solvent, with average discharge capacities of $80 \mathrm{mAh} \mathrm{g}^{-1}$ (at C/5).[32]

\section{Oxide Based-Cathode Materials}

\section{$3.1 \mathrm{MoO}_{3}$}

The layered molybdate, $\mathrm{MoO}_{3}$ (Figure 6), was investigated as a potential host cathode for magnesium batteries, demonstrating 0.50 moles of magnesium/moles of host with an optimal capacity of $143 \mathrm{mAh} \mathrm{g}^{-1}$ determined through the chemical intercalation of $\mathrm{Mg}^{2+}$ $\begin{array}{llllll}\text { using an excess of } & \text { a } & 0.7 & \mathrm{M}\end{array}$ dibutylmagnesium/heptane solution.[33] An ionic liquid containing 56 wt-\% $\mathrm{AlCl}_{3}, 41$ wt\% 1-ethyl-3-methylimidazolium chloride (EMIC), and 3 wt-\% $\mathrm{MgCl}_{2}$ at $80{ }^{\circ} \mathrm{C}$

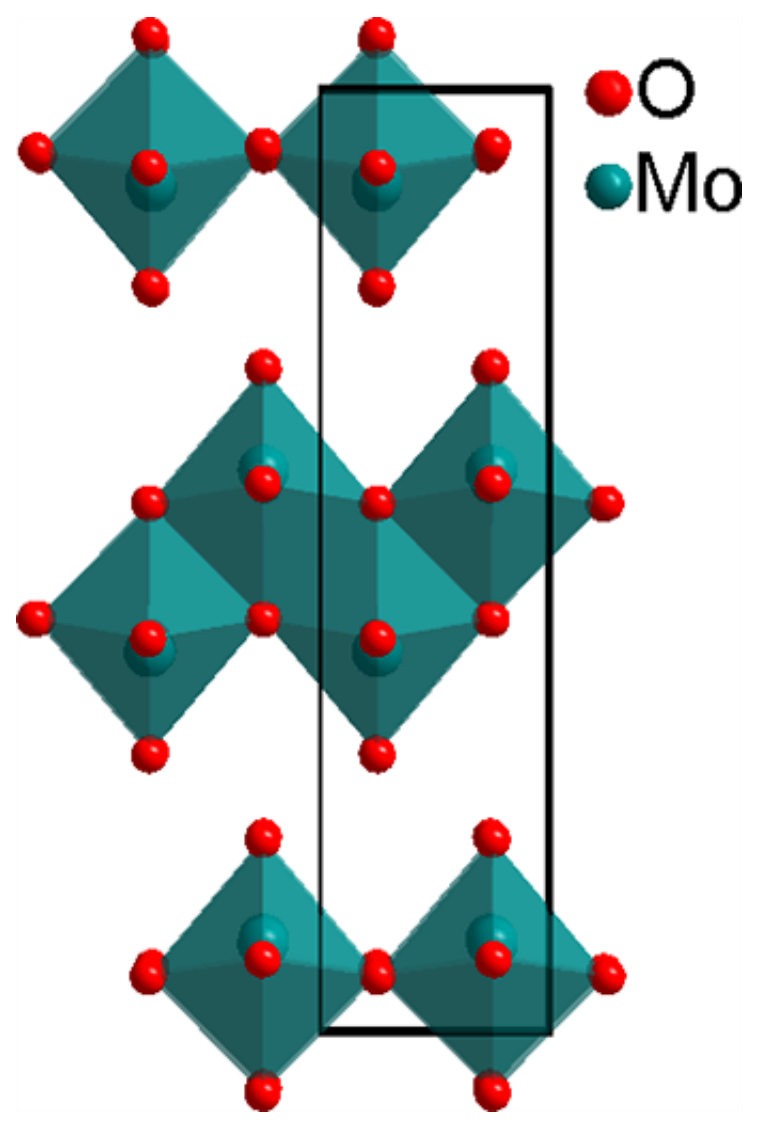

Figure 6. Structure of $\alpha-\mathrm{MoO}_{3}$ viewed along [ $\left[\begin{array}{lll}0 & 1 & 0\end{array}\right]$. 
facilitated an initial discharge capacity of $150 \mathrm{mAh} \mathrm{g}^{-1}$ However significant capacity fade was observed, with discharge capacities falling below $100 \mathrm{mAh} \mathrm{g}^{-1}$ after subsequent galvanostatic cycles between $0.01-0.02 \mathrm{~mA} / \mathrm{g}$.[14] Further investigation of $\mathrm{MoO}_{3}$, outside the use of wet organic-based electrolytes[34] has not been reported.

$3.2 \alpha-\mathrm{MnO}_{2}$

$\mathrm{MnO}_{2}$, with its variety of crystalline polymorphys and microstructures[35] that have been used as successful host storage materials for lithium-ion batteries[36,37], has continued to be a target for divalent battery systems. With a $(2 \times 2)$ tunnel structure (Figure 7$), \alpha-\mathrm{MnO}_{2}$ contains suitable channels for the insertion/extraction of $\mathrm{Mg}^{2+}$ upon subsequent reduction/oxidation of manganese ions. While initial reports demonstrated magnesium insertion/extraction, the electrolytes employed were not compatible with a magnesium metal anode.[38] Nonetheless, using a $0.2 \mathrm{M}$ Mg-HMDS $\left(\mathrm{Mg}_{2}(\mu-\mathrm{Cl})_{3} \cdot 6\left(\mathrm{OC}_{4} \mathrm{H}_{8}\right)\right)\left(\left(\mathrm{N}\left(\mathrm{Si}_{(}\left(\mathrm{CH}_{3}\right)_{3}\right)_{2}\right)_{n} \mathrm{AlCl}_{4-n}\right)(n=1,2)[39]$ electrolyte in THF solvent demonstrated an initial specific capacity of $280 \mathrm{mAh} / \mathrm{g}$ (at $1.5 \mathrm{~mA} / \mathrm{g}$

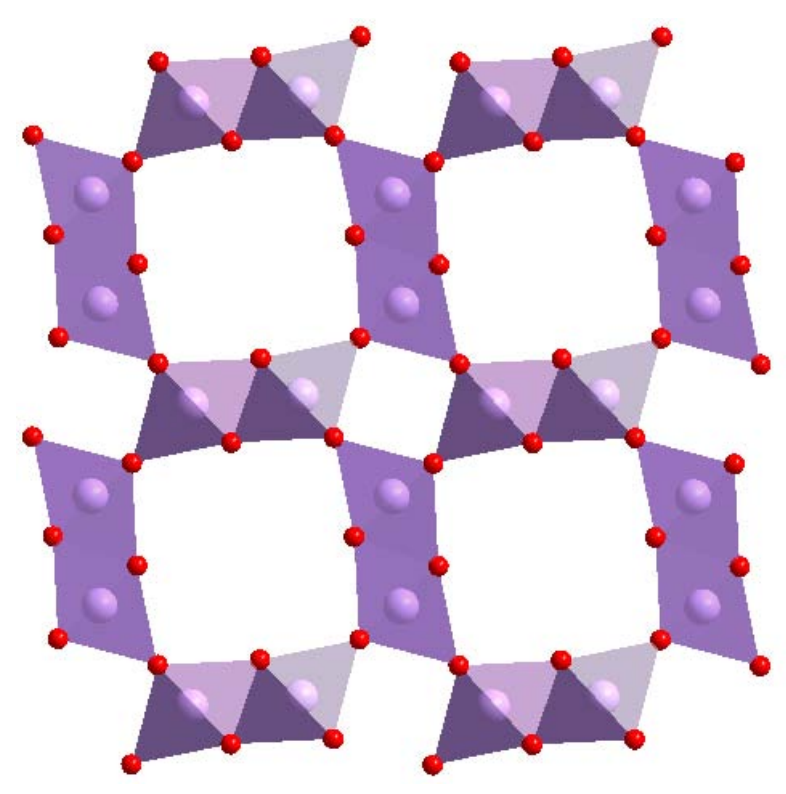

Figure 7. Structure of $\alpha-\mathrm{MnO}_{2}$ viewed along [1 100$]$. current) while employing commercially available nano-sized $\quad \alpha-\mathrm{MnO}_{2}$. Unfortunately upon successive cycles of magnesium insertion/extraction, a collapse of the tunneled structure leads to irreversible capacity fade (50 \%).[15] Despite a large capacity fade $\alpha-\mathrm{MnO}_{2}$, allows for high voltage electrolyte compositions to be examined[40] since its electrochemical stability window 
exceeds that of $\mathrm{CP}-\mathrm{Mo}_{6} \mathrm{~S}_{8}\left(3.5 \mathrm{~V}\right.$ vs. $\left.\mathrm{Mg}^{2+/ 0}\right)$ while maintaining comparable gravimetric capacities.

\section{Conclusions}

Although magnesium-based batteries offer a two-fold increase in theoretical volumetric energy density and improved safety when employing a pure metal anode, the chemistry associated with the divalent $\mathrm{Mg}^{2+}$ adds significant complexity that has not observed for lithiumion predecessors. Recently, significant advances have been made in high-voltage cathode materials that show $\mathrm{Mg}^{2+}$ insertion/extraction within water-containing electrolytes. While oxidebased cathode materials demonstrate large electrode potentials for $\mathrm{Mg}^{2+}$ insertion/extraction, their affinity for the weakly polarizable $\mathrm{Mg}^{2+}$ cation results in slow ion diffusion. For this reason, water is often added to the electrolyte since water is a strong enough Lewis base to provide temporary solvation of $\mathrm{Mg}^{2+}$, leading to enhanced diffusion kinetics of the highly charge dense ion. However, aqueous solutions or even water-contaminated nonaqueous solutions will likely not be compatible with magnesium metal anodes due to the proclivity to react: $\mathrm{Mg}^{0}+\mathrm{H}_{2} \mathrm{O} \rightarrow$ $\mathrm{MgO}+\mathrm{H}_{2} \cdot[20]$

Recent reports of electrode materials that demonstrate compatibility with magnesium metal anodes show that materials composed of large polarizable metals and relatively soft Lewis bases $\left(\mathrm{CP}-\mathrm{Mo}_{6} \mathrm{~S}_{8}, \mathrm{MoS}_{2}\right.$, and $\left.\mathrm{WSe}_{2}\right)$ provide reversible insertion and extraction pathways. There are fewer reports using less polarizable oxides, although structures having either weak Van der Waals interactions between layered structures $\left(\alpha-\mathrm{MoO}_{3}\right)$ or those with large ion channels for intercalation $\left(\alpha-\mathrm{MnO}_{2}\right)$ have emerged. Oxides suffer from significant capacity fade upon successive cycling. As a result, cathode materials for next-generation magnesium batteries will 
likely consist of first-row transition metals with polarizable anions to allow for long-term successful insertion/extraction Additionally, implementing nanostructured materials to further aid in enhanced solid state diffusion of the highly charge dense magnesium-ion will likely aid in advancing the science of magnesium-ion batteries. Further advancements in developing practical $\mathrm{Mg}^{2+}$ batteries may require the use of alloy-based anodes containing either bismuth or tin[41-43] or the reinvestigation of other solid state cathode materials that have been previously restricted to non-magnesium anode compatible electrolyte solutions.

\section{Acknowledgements}

This research was supported in part by a grant from the National Science Foundation (DMR1253347). 


\section{References}

[1] A. Manthiram, Y. Fu, Y.S. Su, Acc. Chem. Res. 46 (2013) 1125-1134.

[2] A. Greenwood, N.Earnshaw, Chemistry of the Elements, Butterworth-Heinemann: Oxford, 1997.

[3] J. Muldoon, C.B. Bucur, T. Gregory, Chem. Rev. 114 (2014) 11683-11720.

[4] L.W. Gaddum, H.E. French, J. Am. Chem. Soc. 49 (1927) 1295-1299.

[5] D. Aurbach, I. Weissman, Y. Gofer, E. Levi, Chem. Rec. 3 (2003) 61-73.

[6] Z. Feng, Y. NuLi, J. Wang, J. Yang, J. Electrochem. Soc. 153 (2006) C689.

[7] D. Aurbach, Z. Lu, A. Schechter, Y. Gofer, H. Gizbar, R. Turgeman, Y. Cohen, M. Moshkovich, E. Levi, Nature 407 (2000) 724-727.

[8] D. Aurbach, Y. Gofer, Z. Lu, A. Schechter, O. Chusid, H. Gizbar, Y. Cohen, V. Ashkenazi, M. Moshkovich, R. Turgeman, E. Levi, J. Power Sources 97-98 (2001) 28-32.

[9] O. Crowther, A.C. West, J. Electrochem. Soc. 155 (2008) A806.

[10] D. Aurbach, Y. Gofer, A. Schechter, O. Chusid, H. Gizbar, Y. Cohen, M. Moshkovich, R. Turgeman, J. Power Sources 97-98 (2001) 269-273.

[11] D. Aurbach, G.S. Suresh, E. Levi, A. Mitelman, O. Mizrahi, O. Chusid, M. Brunelli, Adv. Mater. 19 (2007) 4260-4267.

[12] Y. Liang, R. Feng, S. Yang, H. Ma, J. Liang, J. Chen, Adv. Mater. 23 (2011) 640-643.

[13] B. Liu, T. Luo, G. Mu, X. Wang, D. Chen, G. Shen, ACS Nano 7 (2013) 8051-8058.

[14] M.E. Spahr, P. Novak, O. Haas, R. Nesper, J. Power Sources 54 (1995) 346-351.

[15] R. Zhang, X. Yu, K.W. Nam, C. Ling, T.S. Arthur, W. Song, A.M. Knapp, S.N. Ehrlich, X.Q. Yang, M. Matsui, Electrochem. Commun. 23 (2012) 110-113.

[16] E. Levi, G. Gershinsky, D. Aurbach, O. Isnard, G. Ceder, Chem. Mater. 21 (2009) 13901399.

[17] G.G. Amatucci, F. Badway, A. Singhal, B. Beaudoin, G. Skandan, T. Bowmer, I. Plitz, N. Pereira, T. Chapman, R. Jaworski, J. Electrochem. Soc. 148 (2001) A940.

[18] E. Levi, A. Mitelman, D. Aurbach, M. Brunelli, Chem. Mater. 19 (2007) 5131-5142.

[19] B. Zhou, H. Shi, R. Cao, X. Zhang, Z. Jiang, Phys. Chem. Chem. Phys. 16 (2014) 1857818585.

[20] K.W. Nam, S. Kim, S. Lee, M. Salama, I. Shterenberg, Y. Gofer, J.-S. Kim, E. Yang, C.S. Park, J.-S. Kim, S.-S. Lee, W.-S. Chang, S.G. Doo, Y.N. Jo, Y. Jung, D. Aurbach, J.W. Choi, Nano Lett. (2015) 4071-4079.

[21] P. Novák, J. Electrochem. Soc. 140 (1993) 140.

[22] M.M. Huie, D.C. Bock, E.S. Takeuchi, A.C. Marschilok, K.J. Takeuchi, Coord. Chem. Rev. 287 (2015) 15-27. 
[23] P. Saha, M.K. Datta, O.I. Velikokhatnyi, A. Manivannan, D. Alman, P.N. Kumta, Prog. Mater. Sci. 66 (2014) 1-86.

[24] I. Shterenberg, M. Salama, Y. Gofer, E. Levi, D. Aurbach, MRS Bull. 39 (2014) 453-460.

[25] E. Lancry, E. Levi, Y. Gofer, M. Levi, G. Salitra, D. Aurbach, Chem. Mater. 16 (2004) 2832-2838.

[26] A. Mitelman, M.D. Levi, E. Lancry, E. Levi, D. Aurbach, Chem. Commun. (2007) 42124214.

[27] E. Levi, A. Mitelman, O. Isnard, M. Brunelli, D. Aurbach, Inorg. Chem. 47 (2008) 19751983.

[28] X.L. Li, Y.D. Li, J. Phys. Chem. B 108 (2004) 13893-13900.

[29] Y. Liu, L. Jiao, Q. Wu, J. Du, Y. Zhao, Y. Si, Y. Wang, H. Yuan, J. Mater. Chem. A 1 (2013) 5822-5826.

[30] Z. Lu, A. Schechter, M. Moshkovich, D. Aurbach, J. Electroanal. Chem. 466 (1999) 203217.

[31] Y. Liu, J.S. Xue, T. Zheng, J.R. Dahn, Carbon N. Y. 34 (1996) 193-200.

[32] E.G. Nelson, S.I. Brody, J.W. Kampf, B.M. Bartlett, J. Mater. Chem. A 2 (2014) 1819418198.

[33] T.D. Gregory, R.J. Hoffman, R.C. Winterton, J. Electrochem. Soc. 137 (1990) 775-780.

[34] G. Gershinsky, H.D. Yoo, Y. Gofer, D. Aurbach, Langmuir 29 (2013) 10964-10972.

[35] O. Ghodbane, J.L. Pascal, F. Favier, ACS Appl. Mater. Interfaces 1 (2009) 1130-1139.

[36] S. Bach, Solid State Ionics 80 (1995) 151-158.

[37] C.S. Johnson, D.W. Dees, M.F. Mansuetto, M.M. Thackeray, D.R. Vissers, D. Argyriou, C.-K. Loong, L. Christensen, J. Power Sources 68 (1997) 570-577.

[38] G.G. Kumar, N. Munichandraiah, J. Power Sources 102 (2001) 46-54.

[39] H.S. Kim, T.S. Arthur, G.D. Allred, J. Zajicek, J.G. Newman, A.E. Rodnyansky, A.G. Oliver, W.C. Boggess, J. Muldoon, Nat. Commun. 2 (2011) 427.

[40] O. Tutusaus, R. Mohtadi, T.S. Arthur, F. Mizuno, E.G. Nelson, Y.V. Sevryugina, Angew. Chemie Int. Ed. 54 (2015) 7900-7904.

[41] N. Singh, T.S. Arthur, C. Ling, M. Matsui, F. Mizuno, Chem. Commun. 49 (2013) 149151.

[42] Y. Shao, M. Gu, X. Li, Z. Nie, P. Zuo, G. Li, T. Liu, J. Xiao, Y. Cheng, C. Wang, J.G. Zhang, J. Liu, Nano Lett. 14 (2014) 255-260.

[43] T.S. Arthur, N. Singh, M. Matsui, Electrochem. Commun. 16 (2012) 103-105. 